\title{
Descriptive analysis of sub catchment associations' contribution to management of water use conflicts in the Great Ruaha River of southern Tanzania
}

\author{
N. J. Ngowi ${ }^{1}$ \& E. Makfura ${ }^{2}$ \\ ${ }^{1}$ Institute of Development Studies, Mzumbe University, Tanzania \\ ${ }^{2}$ WWF - Ruaha Water Programme, Tanzania
}

\begin{abstract}
Human activities accelerate the loss of environmental flow of many rivers and bring water shortages, resulting in water use conflicts. In Africa, such conflicts have contributed to water resource governance challenges. However, little is known on the role of the sub catchment water associations in managing water use conflicts in some river basins of Tanzania. Given this need, our objectives were to: (1) explore the causes of water use conflicts in the prone areas of the sub catchments; and (2) understand the role of sub catchment water associations in the management of such conflicts. We addressed these objectives using physical observations, unstructured interviews, in-depth interviews, focus group discussions and questionnaires administered to 100 households in the 4 villages within Mambi and Mpolo sub catchments of the Great Ruaha River in southern highlands, Tanzania. The findings showed that $(46 \%)$ of conflicts in the upstream areas were caused by water theft, water scarcity (38\%) and use of water without water right (12\%). Excessive use of water by upstream users $(46 \%)$, big number of livestock $(38 \%)$ and illegal water connections $(12 \%)$ were the main sources of conflicts in the downstream areas. We found that sub catchment water associations have been using meetings $(55 \%)$, bylaws $(12 \%)$, dialogue $(12 \%)$ and combination of meetings and bylaws and dialogue (21\%) to manage water use conflicts. Payment for Environmental Services has been recommended to reduce water use conflicts in the area.
\end{abstract}

Keywords: sub catchment, water use conflicts, vinyungu, Ruaha. 


\section{Introduction}

Over two billion people in about 40 countries live in the water stressed river basins, World Bank [1]. Under such situation, management of water resources is imperative to ensure sustainable development. In sub-Saharan Africa, poor water resources management has led to an increase in the number of problems such as reduction of river flows, water-borne related health problems and conflicts (Dungumaro and Madulu [2]). The legal and regulatory framework for water resources management (WRM) in Tanzania was made before independence (Sokile and Van Koppen [3]). At the basin level, there are formal and informal arrangements, but the formal predominates, partly because the informal arrangements are often still localized and do not encompass the whole basin as yet, and also due to the general failure of the formal basin-level water management system to appreciate the informal organs (Sokile et al. [4]). At the catchment and sub catchment levels, informal institutions have gain strengths and the patterns of the formal-informal interface have become clearer (Sokile et al. [5]). The National Water Policy of 2002, (URT [6]) recognizes the difficult task of managing water resources on its scale due to extensive nature of most of the river basins. Different efforts have been made by the Government of Tanzania in collaboration with other stakeholders to empower communities at the lower levels to manage water resources and the associated conflicts (Cleaver and Toner [7]).

Despite existence of various institutions, water resources management remains elusive, and consequently conflicts over water use are common (GWP [8]). While different studies [3-5] have been conducted in the study area in relation to WRM, some have questioned the role of sub catchment water associations in managing water use conflicts occurring in the sub catchments. Given this need, our objectives were to: (1) explore the causes of water use conflicts in the prone areas of the sub catchments; and (2) understand the role of sub catchment water associations in the management of water use conflicts. We addressed these objectives using physical observations, semi-structured interviews, in-depth interviews, focus group discussions and questionnaires addressed to households in 4 villages of Mambi and Mpolo sub catchment of the Great Ruaha River (GRR) in southern highlands of Tanzania between 2010 and 2011.

\section{Materials and methods}

\subsection{Study area}

This study involved Mambi and Mpolo sub catchments in Mbarali District which lies between latitudes 7'48 and 9'25 South and longitudes 23'40' and 34'09 East in the heart of the GRR (Bruce and Mahoo [9]). These sub catchments form part of Usangu catchment and important tributaries of the GRR in the Rufiji Basin. Water from Mambi and Mpolo sub catchments are used mainly in irrigated agriculture including paddy cultivation and by the agro-pastoral livelihoods in 
the downstream. The sub catchments of GRR in Mbarali District were selected due to occurrences of many water use conflicts among users. Figure 1 shows the location of Mswisi/Mambi and Mpolo sub catchments among sub catchments of the Usangu catchment in the GRR.

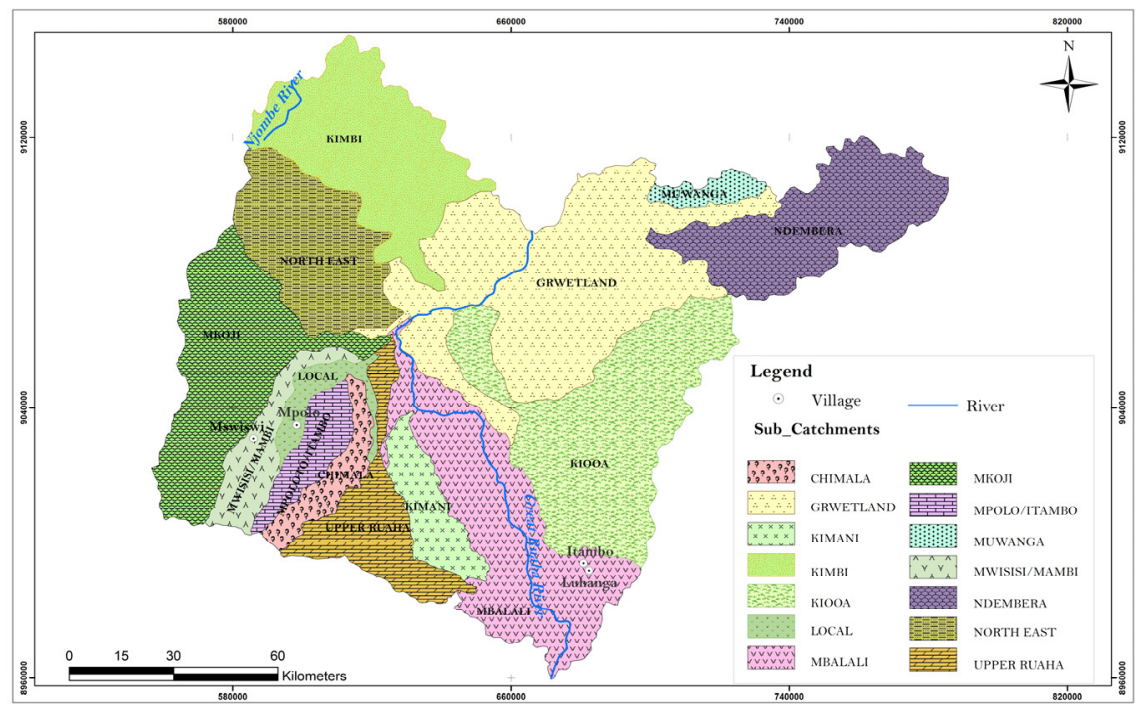

Figure 1: A map of Usangu catchment showing location of Mswisi/Mambi and Mpolo sub catchments in the GRR within Rufiji Basin, Tanzania.

\subsection{Methods}

The study used triangulation method to collect both qualitative and quantitative data. The primary data were collected using interviews, questionnaires, physical observations and focused group discussion (FGD). A cross sectional survey was used to understand the role of sub catchment water associations in managing water use conflicts occurring in the prone areas of the GRR catchments. Four study villages Mwisisi/Mambi and Luhanga from (Mswisi/Mambi) and Mpolo and Itambo from (Mpolo) sub catchments were randomly selected out of 15 villages.

Proportional random sampling techniques (Ngechu [10]) were employed in selecting 110 respondents composing of 100 households and 10 key informants.

A documentary review method was used to gather secondary data from published and unpublished government reports on sub catchment Water User Associations (WUAs) and the water use conflicts in the area from the District, Region, Rufiji Basin Water Office and the Ministry of Water. 


\section{Results}

\subsection{Socio-economic characteristics of the respondents}

\subsubsection{Gender and settlement of the respondents}

The findings show that $61 \%$ of the respondents were males and $39 \%$ females. Furthermore, the findings show that $51 \%$ of the respondents settled in the upstream and $49 \%$ in the downstream of the sub catchment of GRR as shown in table 1.

Table 1: Respondents' settlement.

\begin{tabular}{|l|c|c|}
\hline $\begin{array}{l}\text { Location of the } \\
\text { respondents }\end{array}$ & No of respondents & Percent \\
\hline Upstream & 56 & 51 \\
\hline Downstream & 54 & 49 \\
\hline Total & 110 & 100 \\
\hline
\end{tabular}

\subsection{The cause of water use conflicts in the prone areas of the sub catchments}

\subsubsection{Causes of conflicts in the upstream areas}

The findings show that $46 \%$ of the said that water use conflicts in the upstream areas were caused by excessive water theft. $38 \%$ of the respondents reported that conflicts were caused by water scarcity. $12 \%$ mentioned that the location of the bottom valley farms called vinyungu were the main sources of water use conflicts in the upstream areas. 3\% show the use of water without water right; and $1 \%$ reported that poor infrastructures were the drivers for water use conflicts as it leads to water loss through leakages. Upstream users identified water use conflicts occur due to excessive water theft. The water scarcity in the rivers could be caused by prolonged drought and poor farming methods including location of vinyungu which use a lot of water particularly during the night.

\subsubsection{Causes of conflicts in the downstream areas}

The findings show that $46 \%$ of the respondents said that water use conflicts in the downstream areas were caused by excessive use of water by upstream users, while $38 \%$ of the respondents said the big number of livestock was the main cause. $3 \%$ of respondents said water shortage was another source while $1 \%$ mentioned position of vinyungu was the source of water use conflict. About $12 \%$ of the respondents said that illegal connections of water were the cause of water use conflict in the downstream areas.

\subsubsection{The frequency of occurrence of conflicts}

The findings show that $87 \%$ of respondents reported that water use conflicts occur several times. About $10 \%$ of the respondents reported that water use conflicts in their area occurred rarely. 3\% reported that water use conflicts had 
never happened in their areas. $85 \%$ of respondents show that water use conflicts occurred mainly during the dry season, while $15 \%$ of the respondents reported that water use conflicts occurred during the rainy season.

\subsubsection{Effect of the conflicts}

$54 \%$ of the respondents said that water use conflicts had caused misunderstanding among community members, while $29 \%$ said that water use conflicts had caused group wars. $7 \%$ of the respondents said water use conflicts had created insecurity in the area, while $10 \%$ of the respondents said that water use conflicts have break peace and tranquillity among community members as shown in table 2 .

Table 2: The effect of water use conflicts.

\begin{tabular}{|l|c|c|}
\hline Effect of conflicts & No of respondents & Percent \\
\hline $\begin{array}{l}\text { Misunderstandings among } \\
\text { community members }\end{array}$ & 59 & 54 \\
\hline Group wars & 32 & 29 \\
\hline Insecurity & 8 & 7 \\
\hline Breaking of peace and tranquillity & 11 & 10 \\
\hline Total & 110 & 100 \\
\hline
\end{tabular}

\subsection{The role of sub catchment water user associations in the management of water use conflicts}

The findings show that there were two sub catchments water user associations (WUAs) operating in the study area. The JUABOMA for Mswisi/Mambi and MUABOMA for Mpolo sub catchment. 35\% of the respondents said that the functions of the sub catchment water associations were to protect water resources; while 4\% said the functions of WUAs were to prepare meetings for water users. $5 \%$ of the respondents said follow up of water user right, while $41 \%$ said the functions of the sub catchment WUAs were to resolve water use conflicts. $5 \%$ of the respondents described the roles of WUAs were to enforce bylaws and $8 \%$ said the role was to provide education to the water users. $2 \%$ of the respondents said that the functions of sub catchment WUAs were to punish violators of the bylaws as shown in table 3 .

The findings show that $98 \%$ of the respondents report that WUAs had been involved in the water conflicts resolution several times, while $2 \%$ had never been involved.

\subsubsection{Methods used by sub catchment WUAs in resolving water use conflicts}

The findings show that $21 \%$ of the respondents said that water use conflicts were resolved through meetings, while $12 \%$ of the respondents said that water use conflicts were resolved using existing bylaws. $12 \%$ reported that water use conflicts were resolved through dialogue. About $55 \%$ of respondents said that 
Table 3: Functions of sub catchment associations.

\begin{tabular}{|l|c|c|}
\hline Functions of sub catchment WUAs & No of respondents & Percent \\
\hline Protecting water resources & 39 & 35 \\
\hline Preparing meeting for water users & 4 & 4 \\
\hline Follow up water right & 5 & 5 \\
\hline Resolving water use conflicts & 45 & 41 \\
\hline Enforcement of bylaws & 6 & 5 \\
\hline $\begin{array}{l}\text { Providing education to the water } \\
\text { users }\end{array}$ & 9 & 2 \\
\hline $\begin{array}{l}\text { To punish those who go against the } \\
\text { rules }\end{array}$ & 2 & 100 \\
\hline Total & 110 & \\
\hline
\end{tabular}

water use conflicts were resolved using meetings, existing bylaws and dialogue. It shows that most of the water use conflicts occurring in the sub catchments were resolved amicably by the sub catchment WUAs.

\subsubsection{Time spent by sub catchment WUAs to resolve water use conflicts}

$65 \%$ of the respondents said that many times sub catchment WUAs were used to solve water use conflicts, while $35 \%$ of the respondents said sub catchment WUAs were used occasionally.

\subsubsection{Methods used to punish violators}

The respondents showed that sub catchment WUAs used different methods in punishing those who went against the existing bylaws. The findings show that $30 \%$ of respondents said that those who went against bylaws were warned by sub catchment WUAs, while $23 \%$ of the respondents said that penalties were used. $47 \%$ reported that both warning and penalties were used as shown in table 4 .

Table 4: Methods used to punish those who went against the water rules.

\begin{tabular}{|l|c|c|}
\hline Methods used to punish violators & No of respondents & Percent \\
\hline Warnings & 33 & 30 \\
\hline Penalties & 25 & 23 \\
\hline Both warning and penalties & 52 & 47 \\
\hline Total & 110 & 100 \\
\hline
\end{tabular}

\subsubsection{Other stakeholders involved in the management of water use conflicts}

The study revealed that in addition to the sub catchment WUAs, there were other stakeholders involved in the management of water use conflicts. The findings show that other than $16 \%$ of the respondents who reported that sub catchment WUAs were responsible for managing water resource use conflicts, $6 \%$ of the 
respondents reported that Worldwide Fund for Nature (WWF) was responsible for managing water use conflicts. $18 \%$ of respondents said that Rufiji Basin Water Office (RBWO) was responsible for managing water use conflicts. About $40 \%$ of the respondents showed that both sub catchment WUAs and RBWO were responsible for managing water conflicts, while $13 \%$ said that sub catchment WUAs, WWF and informal institutions were responsible for managing water conflicts. Only $2 \%$ and $5 \%$ said that sub catchment WUAs, informal institutions and RBWO were responsible for managing water use conflicts. The existence of different stakeholders as shown in table 5 indicates that most of the conflicts were solved on case by case by a particular institution than by all institutions in a holistic manner.

Table 5: Stakeholders responsible for water use conflicts management.

\begin{tabular}{|l|c|c|}
\hline $\begin{array}{l}\text { Institutions responsible for } \\
\text { managing water use conflicts }\end{array}$ & No of respondents & Percent \\
\hline Sub catchment WUAs & 18 & 16 \\
\hline WWF & 7 & 6 \\
\hline RBWO & 20 & 18 \\
\hline $\begin{array}{l}\text { Sub catchment WUAs and } \\
\text { RBWO }\end{array}$ & 14 & 13 \\
\hline $\begin{array}{l}\text { Sub catchment WUAs, WWF and } \\
\text { informal institutions }\end{array}$ & 2 & 2 \\
\hline $\begin{array}{l}\text { Sub catchment WUAs, WWF and } \\
\text { RBWO }\end{array}$ & 5 & 5 \\
\hline $\begin{array}{l}\text { Sub catchment WUAs, WWF, } \\
\text { informal institutions and RBWO }\end{array}$ & 110 & 100 \\
\hline Total & & 40 \\
\hline
\end{tabular}

\section{Discussion}

\subsection{Socio-economic characteristics of the respondents}

More male than female respondents were reported living in the study area. This could be explained by the role played by men in allocation, control and management of water and their associated conflicts. AWEC report [11] showed that communities have different priorities on the use of water which are segregated on the basis of gender where men and women often tend to have different roles, priorities and responsibilities. Where women may be interested with domestic water availability, men were interested with water for economic production activities such as irrigation and livestock. The findings also show that more respondents lived in the upstream than the downstream. These findings are supported by IUCN [12] study which showed that upstream users were more favorably vis-a-vis water abstraction than downstream users. Therefore competition for water has led to unauthorized water abstractions henceforth conflicts. 


\subsubsection{Causes of water use conflicts in the prone areas of the sub catchments}

The study revealed that water use conflicts exist in the area. The upstream water use conflicts were caused by excessive water abstraction, water scarcity, water rights and position of the vinyungu farms. While conflicts in the downstream areas were caused by excessive abstraction of water by upstream users, big number of livestock, shortage of water, position of vinyungu farms and illegal water connections. Thus, the management of sub catchment WUAs for the sustainable use of water resources required the resolution of water conflicts among competing users within the sub catchments, taking into account the needs of present and future generations. Therefore, members of the community and other stakeholders should be encouraged to participate in identifying and resolving critical sub catchment water problems in their areas as they arise. A study by World Bank [1] showed that water resources development and management should be participatory, involving users, planners and policy makers at all levels.

\subsubsection{The frequency of occurrence of water use conflicts}

This study has established that water use conflicts occur several times especially during the dry season. This is because during the dry season water is highly needed by different users in irrigation especially in the paddy cultivation, maize and beans farms and vegetable growers as well as livestock. Therefore competition for water has led to unauthorized water abstractions henceforth conflicts. Joseph [13] showed that unauthorized use of water, particularly in brick making industry during the dry season were the two biggest water management challenges facing domestic users. The difficult moment to people of the study area starts July and ended in April. In July to December, they not only face problems for their livestock, but also they faced serious water shortage for irrigation. For domestic use the critical period was from June to December. This is the dry season when most of rivers in the sub catchment were usually short leading to few abstractions of water at the domestic user's main off-take. As far as paddy cultivators are concerned, the critical period was from April to November. In this period, rice cultivators need enough water until harvesting time. In one of the interview session, one respondent said "many conflicts occur during paddy planting time because it is the period when many farmers need water. In this period, fighting occur several times and sometimes men never sleep at home for a week".

For the livestock keepers the critical period was from July to December, when all seasonal ponds dry up. In Mambi sub catchment, particularly in Luhanga village, the situation was worse for those who were involved in both paddy cultivation and animal keeping.

\subsection{The role of sub catchment water associations in the management of water use conflicts}

The findings show that local communities play great role in the water resources management because they are primarily users, guardians and managers of water. Therefore, local communities used sub catchment WUAs several times in 
resolving water use conflicts because they usually operate at their level. IUCN, [12] showed that establishment of catchment associations is considered as a mechanism that will enhance conflict resolution in the basins which are facing challenges of increasing water demands already overstretched with the water resources and impacts of climate change. The majority of the respondents used WUAs in resolving water conflicts. This could be possibly because sub catchments WUAs are close to community members. Therefore, it could be easy to mobilize them and discuss issues related to water management and conflict resolution. The sub-catchment WUAs perform other equally different functions including water resources protection, organizing meetings with community members and follow up of water use rights. IUCN, [14] showed that, through policy and legal framework, river basin management assist the basin water boards to establish sub-catchment WUAs for water use conflicts management among others. IUCN, [15] showed that once WUAs are established, they raise awareness among community members and other stakeholders to participate in water management issues.

\subsubsection{Methods used by sub catchment WUAs in resolving water use conflicts}

We established that sub catchment WUAs play great role in handling water use conflicts in the area. Some of the methods used include meetings, bylaws and dialogue. Users who go against the rules were taken to court and fined. Sub catchment WUAs were also responsible for water resources management through awareness raising to communities, planting of trees near water sources, allocation and distribution of water.

\subsubsection{Methods used to punish violators of the rules}

This study showed that different methods were used to punish the wrong doers. However, the methods differed from one sub catchment to another within the same basin depending on the nature of the village bylaws. These included warnings and penalties or both warning and penalty. When amicable methods fail, wrong doers were taken to court and fined.

\subsubsection{Other stakeholders responsible for water use conflicts management}

WWF and RBWO were among the key stakeholders involved in the management of water use conflicts in the area. These stakeholders have knowledge on environment, water resources planning, conflict resolution and mobilization skills. A study of IUCN, [15] showed that stakeholder participation in the management of water resources is important. The catchment forum assisted delegation of basin office roles, sharing of information and conflict resolution. It can further be argued that through stakeholder platforms, districts had been assisting in the formation of sub catchment WUAs towards water use conflict resolution. Due to its significance the sub catchment WUAs need be reinforced and this is supported in Water Act, No. 11, 2009 URT [16]. 


\section{Conclusion}

The study showed that water use conflicts were common in the prone areas of Mambi and Mpolo sub catchments indicating poor governance of water resources in the GRR. The sub catchment WUAs and other stakeholders like WFF and RBWO have played a great role in the management of water use conflicts in the area. While sub catchment WUAs are considered good local institutions for conflict resolution in the GRR, their registration has been hampered by the long process. The study recommends the approach used by sub catchment WUAs in resolving conflicts be harmonized with the existing rules and regulations operating in the area in order to address the problem holistically and remove duplication of efforts. In addition, we recommend introduction of the Payment for Environmental Services as a way of reducing water use conflicts in the study area.

\section{Acknowledgements}

This work used some information collected by different projects which have worked in the study area including: Raising Irrigation Productivity and Releasing Water for Inter Sectoral Needs (RIPARWIN) project, Smallholder Irrigation Improvement Project (SIIP), Sustainable Management of the Usangu Wetlands and its Catchment (SMUWC) and WWF Ruaha Water Programme. We acknowledge them all. We are grateful to communities in the Mambi and Mpolo sub catchments for their cooperation and for sharing their knowledge and experiences with us. In addition, authors would like to thank Mbarali District Executive Director and leaders of Mswisi/Mambi, Luhanga, Mpolo and Itambo villages for logistic support and participating in the research.

\section{References}

[1] World Bank, Lessons for Managing Lake Basins for Sustainable Use. Environment Department and Socially Sustainable Development, Report No 32877, Washington, 2005.

[2] Dungumaro, W. E. \& Madulu, F. N., Public Participation in Integrated Water Resources Management: The case of Tanzania. WaterNet/Warfsa Symposium "Water Demand Management for Sustainable Development", Dar es Salaam, 30-31 October, 2002.

[3] Sokile, C. S. \& Van Koppen, B., Local Water Rights and Local Water User Entities, The Unsung Heroines to Water Resources Management in Tanzania, A paper presented at the WATERNET/WARFSA $4^{\text {th }}$ Symposium, Gaborone, Botswana, October, 2003.

[4] Sokile, C. S., Van Koppen B., Charles, B., Hatibu, N., Lankford, B., Mahoo, H. F. \& Yanda, P. Z., Formal Water Rights in Rural Tanzania, Deepening the Dichotomy, International Water Management Institute (IWMI), Johannesburg, 2004. 
[5] Sokile, C. S., Mwaruvanda, W., \& van Koppen, B., Integrated Water Resources Management in Tanzania, Interface between formal and informal Institutions, International workshop on African Water Laws, Plural legislative Frameworks for Rural Water Management in Africa, Johannesburg, 26-28 January, 2005.

[6] United Republic of Tanzania (URT), The National Water Policy, Ministry of Water, Dar es Salaam, 2002.

[7] Cleaver, F. \& Toner, A., The Evolution of Water Governance in Uchira, Tanzania, The Implications for equality of access, sustainability and effectiveness, Natural Resources Forum, 30, pp. 207-214, 2006.

[8] Global Water Partnership (GWP), Integrated Water Resource Management, TAC Background papers, No 4, Stockholm, 2000.

[9] Bruce, A. L. \& Mahoo, H. F., (eds), Proceedings of the East Africa Integrated River Basin Management Conference, Soil Water Management Research group, Sokoine University of Agriculture, Morogoro, 2005.

[10] Ngechu, M., Understanding the Research Process and Methods, An introduction, University of Nairobi, Nairobi, 2006.

[11] Annual Water Experts Conference (AWEC), Water Sector Development Programme, Arusha, 15-19 January, 2007.

[12] International Union for Conservation of Nature (IUCN) Eastern and Southern Africa Programme, The Situation Analysis Pangani River Basin, 2nd Edition, IUCN, Nairobi, 2009.

[13] Joseph, K., The Role of Water User Associations (WUAs) in Managing Water Resources Conflicts in Tanzania, University of Dar es salaam, Dar es Salaam, 2008.

[14] International Union for Conservation of Nature (IUCN) Eastern and Southern Africa Programme, The Situation Analysis of Ruvu Basin, ESARO Publications Service Unit, Nairobi, 2010.

[15] International Union for Conservation of Nature (IUCN) Eastern and Southern Africa Programme, The Situation Analysis of Wami Basin, ESARO Publications Service Unit, Nairobi, 2010.

[16] United Republic of Tanzania (URT), The water resources management Act, Government printer, Dar es Salaam, 2009. 